\title{
The Erotic as a Liberating and Empowering Force in Two Costa Rican Female Poets: Julieta Dobles and Ana Istarú
}

\author{
Ana Patricia Barquero Vargas \\ Escuela de Lenguas Modernas \\ Universidad de Costa Rica
}

\begin{abstract}
This article explores the erotic poetry of two Costa Rican female writers, Julieta Dobles and Ana Istarú, as a liberating and empowering force. It proposes that these two poets transgress the patriarchal hegemonic discourse through their eroticism, making not only their liberation and empowerment possible but also that of many women who mirror themselves in their poetry. Their corporeal poetry opens a vintage point where they can start scrutinizing their sexual drives and bodies, taking their sex literally into their own hands.
\end{abstract}

Key words: eroticism, empowerment, female sexuality, female identity, hegemonic discourse, patriarchy, libido, Marian dogmatic teaching, male supremacy

\section{Resumen}

Este artículo explora la poesía erótica de dos escritoras costarricenses, Julieta Dobles y Ana Istarú, como una fuerza liberadora y de empoderamiento. Propone que estas poetas transgreden el discurso hegemónico patriarcal por medio del erotismo, haciendo así posible no solamente su liberación y empoderamiento, sino también el de muchas mujeres quienes se ven reflejadas en su poesía. Su poesía corporal abre una perspectiva donde ellas puedan empezar a escudriñar sus deseos sexuales y sus cuerpos, al tomar su sexo literalmente en sus propias manos.

Palabras claves: erotismo, empoderamiento, sexualidad de la mujer, identidad de la mujer, discurso hegemónico, patriarcado, libido, enseñanzas dogmáticas marianas, supremacía masculina 
There are many kinds of power, used and unused, acknowledged or otherwise. The erotic is a resource within each of us that lies in a deeply female and spiritual plane,

firmly rooted in the power of our unexpressed or unrecognized feeling. In order to perpetuate itself, every oppression must corrupt or distort those various sources of power within the culture of the oppressed that can provide energy for change. For women, this has meant a suppression of the erotic as a considered source of power and information within our lives. (Lorde 1)

$\mathrm{T}$ his quote by Caribbean American poet Audre Lorde accurately describes the situation of women around the world, and especially our situation, Central American women, deprived of openly expressing our sexuality because of patriarchal institutions: family, church, marriage, and government. Colonial institutions brought European moralistic customs which endowed the female body with prudery and secrecy. Female bodies were relegated to a dark and private plane, which not even women had access to. Anatomy of the genitalia contributed to this secrecy. Women have been denied the control of their own bodies - they are objects of male sex not subjects of their sex and desire. Their bodies are unexplored vast territories ready to be conquered by female creative power. It is through the writing of the erotic that they will break up past chains and forge the present and the future.

Once, a woman approached Helene Cixous, French Feminist writer and poet, and told her about her experimentation with her own body, to which Cixous comments in "The Laugh of the Medusa," "I wished that that woman would write and proclaim this unique empire [this elaboration of knowledge on the basis of female erotogeneity], so that other women, other unacknowledged sovereigns, might exclaim: I, too, overflow; my desires have invented new desires, my body knows unheard-of songs" (876). Their immaculate bodies must unleash knowledge, knowledge is what makes them powerful, and it is not until women write, as Cixous affirms, that they will bring their bodies back. In Latin America, women's sexuality has been brought to poetry by male writers. Women must move from being mere sex objects to sex subjects in literature. They can no longer continue feeding Western hegemonic discourses, where erotic poetry can turn into pornography in the hands of women.

The term "erotic" has traditionally had two connotations, one "tending to arouse sexual love or desire" and "strongly affected by sexual desire" ("erotic"). In this paper, the erotic will retain these qualities but will go beyond by transforming this desire into metaphorical language. Octavio Paz in his book La llama doble: Amor y eroticismo blends the erotic and the poetic, for both derive from the suggestive-la metáfora. He defines eroticism as

sexualidad transfigurada: la metáfora. El agente que mueve lo mismo al acto erótico que al poético es la imaginación. Es la potencia que transfigura al sexo en ceremonia y rito, al lenguaje. En ritmo y metáfora, la imagen poética es abrazo de realidades opuestas y la rima es cópula de sonidos; la 
poesía erotiza al lenguaje y al mundo porque ella misma, en su modo de operación, es ya erotismo. (10)

Therefore, for him poetry is eroticism because poetry eroticizes both language and the world through the imaginative sphere of metaphors. This substantiates the idea that there is no such thing as pornographic poetry. Luisa Valenzuela, Argentinean writer, affirms that pornography is the opposite of literature:

La pornografía es la negación de la literatura porque es la negación de la metáfora y de la sugerencia, de lo ambiguo. Es una reacción material en el lector, una excitación sexual directa; en cambio el erotismo, que puede ser tremendamente procaz y fuerte, pasa por el filtro de la metáfora y por un lenguaje más poético. La pornografía no entra dentro de la disquisición literaria. (qtd. in Learned 3)

This conceptualization of the erotic and erotic poetry will permeate the discussion of the lascivious and lush poetry of Julieta Dobles and Ana Istarú.

This article proposes that these two Costa Rican female poets transgress the patriarchal hegemonic discourse through their eroticism, making not only their liberation and empowerment possible but also that of many women who mirror themselves in their poetry. Their corporeal poetry opens a vintage point where they can start scrutinizing their sexual drives and bodies, taking their sex literally into their own hands.

In her poetry book, Hojas Furtivas (Furtive Leaves), Dobles shatters some precepts of the Catholic Church by "apostrophing" angelical sex and by defying the image of the woman as immaculate and virginal. In the poem "Angeladas," the solitude and thirst of sexual needs of the persona place her in the position of the Creator, transforming an angel-- this biblical "benevolent celestial being..." ("angel") into a sadicious lover, for this, she first humanizes the divine by endowing him with sudor that smells like the most terrestrial magnolias. Once he is able to secrete bodily fluids, he can perform the most exquisite actions that will satiate her sexual longing, a longing that masturbation is unable to accomplish.

La soledad es un criadero de ángeles.

Terrible soledad que sólo tiembla

En pequeños paréntesis,

Oasis diminutos que no sacian mi sed. (19-22)

In these lines, Dobles personalizes solitude, which only shivers in small parentheses, which are oases incapable of satisfying her thirst fully. She metaphorizes these oases with or through the use of parentheses, which are short moments where in her solitude she self-satisfies her sexual urges. These moments of self-gratification leave her in need of an angel who can fully gratify her desire and sex drive. That is why in line 19, she affirms that solitude is a nursery for angels: "La soledad es un criadero de ángeles." The persona creates this angel to 
command him to strike her down with caresses and with his burning tongue on her parched skin. Julieta Dobles employs an oxymoron and a metaphor in the same lines emphasizing the persona's heat:

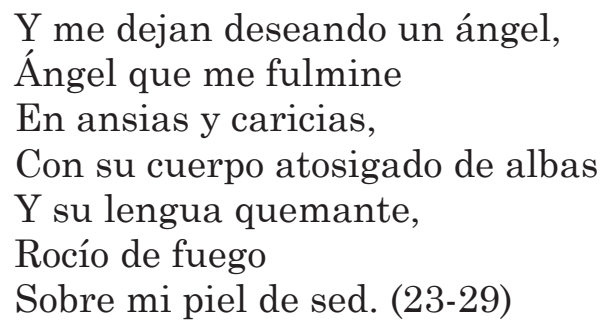

His burning tongue, a mist of fire on her parched skin has a soothing effect. This oxymoronic experience of fire and water continues and gains strength towards the end of the poem:

\section{Un ángel y su ígnea palabra}

Despertando los eros y los vórtices,

Como un dulce y fatal flagelamiento

Sobre mi corazón empecinado. (30-33)

Dobles bequeaths this angel an igneous word that awakens "los eros"; notice that is not Eros, the Greek god of erotic love, but "los eros." Her pluralization of "eros" indicates that the speaker is exploring with different forms to acquire pleasure, thus taking control of her ample sexuality. His igneous word also awakens vortices, which suggests a whirlpool of fluid sucking everything near it toward its center, the vagina. One more time, the persona employs an oxymoronic simile, if one might call it that, to describe this turmoil of exhilarating pleasure: "Como dulce y fatal flagelamiento/sobre mi corazón empecinado." (32-33). This awakening to the eros is like a sweet and fatal flagellation over her hard-headed heart. This female voice not only dares the Creator by transforming His celestial creature into a lecherous lover but also explores sadomasochism, and portrays the pleasure derived from it using the term "flagellation," which has been, for the Roman Catholic Church, a religious practice for the mortification of the flesh. She subversively alludes to and dares to alter tradition and pious practices to fulfill her sexual yearning.

An intriguing aspect of mysticism in the Roman Catholic tradition concerns the issue of ecstasy. For instance, most saints establish an intimate relationship with the Creator, to the point of experiencing intense feelings of ecstasy that can be equated to sexual orgasm or climax. As an illustration, Bernini's religious image "Ecstasy of Saint Teresa" successfully conveys Saint Teresa's elation. In this sculpture, Bernini portrays one of her numerous visions that she described in her books. Her portrayal of this occasion is the following:

Beside me, on the left, appeared an angel in bodily form... He was not tall but short, and very beautiful; and his face was so aflame that he appeared 
to be one of the highest rank of angels, who seem to be all on fire... In his hands I saw a great golden spear, and at the iron tip there appeared to be a point of fire. This he plunged into my heart several times so that it penetrated to my entrails. When he pulled it out I felt that he took them with it, and left me utterly consumed by the great love of God. The pain was so severe that it made me utter several moans. The sweetness caused by this intense pain is so extreme that one cannot possibly wish it to cease, nor is one's soul content with anything but God. This is not a physical but a spiritual pain, though the body has some share in it—even a considerable share. (qtd. in "Bernini's Ectasy")

She accurately expresses this duality of religion and sexual gratification through corporeal language. The words "penetrated", "consumed," and "moans" unequivocally suggest an intimate relationship. In addition, she clearly states that the cut dividing line between physicality and spirituality is very thin.

Another precept of the Catholic Church she undermines is the Marian dogmatic teaching of perpetual virginity or passive female sexuality. The Church teaches that women should imitate the life of Virgin Mary and her eternal virginity. The only viable way in which they can deviate from this is through marriage, in which they tear their immaculate bodies in the name of procreation. For centuries, female sexuality was dichotomized, passive (marital/reproductive) or active (non-reproductive related to prostitution) (Fuchs 7), in other words, the everlasting binary: madonna/whore. Julieta Dobles breaks with this encaged sexuality by creating a female voice that talks about losing her virginity for a second time, having sex freely outside the constraints of marriage, and having a May-December relationship (60-30).

In her poem "Segunda Desfloración" (Second Deflowering), the female speaker depicts her second virginity despoiled of fertility, grace, and pleasure:

Mi segunda virginidad,

Estéril, afrentosa,

Gruta de displaceres (17-19)

By ruing the halo of sanctity and beauty imposed on virginity, Dobles manifests that to be a virgin is disgraceful. In her words, a virgin vagina is a cave of displeasures where Eros hides. Therefore, she expresses her gratitude to the lover whose hands and invading tongue vanished her second virginity:

se esfumó en el asalto de tus manos,

Ante el atrevimiento de tu lengua invasora,

..........

Te agradezco ese golpe de instinto

Que me abrió claridades.

Recorrí, nuevamente,

la dulzura de los cuerpos 
que se van acercando, hasta cerrarse uno sobre otro, como puertas al gozo. Y el jadeo triunfante, música que no puedo desterrar de mi vida (21-22, 31-38)

The female speaker states how sex has opened a new gratifying sphere where the sweetness of their bodies-one on top of the other-is like doors to sensual indulgence and where she can no longer banish the triumphant panting from her life. It is important to mention that her employment of the word "desterrar" (to banish) suggests that with this act, she leaves the patriarchal and Marian frontiers and enters her own delightful land of deflowering.

Finally, she subverts the Catholic Church and male supremacy by turning Jesus Christ into a metonymical figure, a very young lover, in her poem "Sesenta y Treinta." The female speaker is 60 and her young lover 30 . In this poem, her defiant voice turns blasphemous and impious:

Y hoy te amo más, chiquillo,

Con ese celo protector

Que me ata a tu cuerpo,

Tan deseado y tan mío

Cuando te tengo aquí,

Cruzado entre mis sábanas,

Herido por aquella

Antigua cicatriz en el costado

Que yo lamo y beso, silenciosa,

En tímido homenaje a los dolores

Con que el mundo flagela tu juventud. (27-37)

The apostrophe "chiquillo" at the beginning of these lines creates an intimate atmosphere between the two lovers; at the same time, it accentuates the age gap between them. These lines evoke a glimpse at motherly attachment to the lover, but desire and sexual yearning surpass it, or depending on interpretation, this yearning could be strengthened by this motherly and romantic attachment. Then, the female voice alludes to the moments where she feels closer to him and possesses his body-under the sheets. The imagery of the lovers in bed, notwithstanding, blends with the imagery of Jesus Christ wrapped in a white linen when being flagellated. The scar at his side reinforces this metonomy. This is the scar left by the soldiers' piercing of Jesus' side. The images of death and crucifixion are replaced by the resurrected body of "chiquillo" when she licks and kisses this "antigua cicatriz" paying timid homage to the suffering with which the world flagellates his youth.

In the same derisive tone for society, Ana Istarú, I would argue, is the most provocative author of erotic poetry in Costa Rica. Hélene Cixous asserts that women must write from their bodies to create a literature of their own as a way of liberating from the constraints of patriarchy: 
To write [she says]. An act which will not only "realize" the decensored relation of women to her sexuality, to her womanly being, giving her access to her native strength; it will give her back her goods, her pleasures, her organs, her immense bodily territories which have been kept under seal...(880)

At a young age, Istarú began decensoring her relationship to her sexuality through her erotic writing. She initiated the exploration of what it meant "to be a woman" in Latin America and about "the woman she wanted to be." She depicts the tremendous obstacles that arise from being a woman in Latin America:

Ser una mujer. Nadie me advirtió lo difícil de la empresa. Para que se informen quienes aspiran semejante puesto: una mujer no puede (ser mujer se define por los 'no puede') sentarse sola en un parque sin que la hostigue una horroroteca de tipos más feos que el déficit cambiario, salir indemne de un autobús repleto, ser presidente de la FEDEFUTBOL, graduarse de doctora uróloga o decir malas palabras. (Hombres en escabeche 75)

In this passage, she affirms that to be a woman is defined by negation--what she cannot do. She cannot sit at a park without being sexually harassed by the most horrific men, get off a bus unharmed, become the president of a soccer club, graduate from urology, or swear. Through sarcastic writing, Istarú leads women and men to insurgent thought.

Her vibrant and belligerent nature makes her redefine herself, transforming herself into the goddess of lushness, fertility, warfare, and sexual yearning. In her domains, she gives the vagina the most privileged place. As Dr. Acón suggests in her article, "Las variadas estrategias textuales que desestabilizan la cosificación patriarchal de la mujer," Istarú redeems the culture of the vagina and reconstructs the development process of the female sexual identity through her literary work (105). In her poetry collection La estación de fiebre (Fever Season), Istarú goes beyond the irreverent tone of Dobles, by striking down taboos enticing the female body into unrefrained sensual and sexual gratification.

In Poem III, the persona denounces the rules of sexual propriety for women in Central America, so convenient for priests, fathers, and boyfriends, since they make sure women remain virginal, one of the Marian dogmatic teachings:

Y no lastima

Al parecer

Las intenciones puras

De tantos curas.

El novio se contenta,

Al padre alienta

Que en América Central

Siempre se encuentra

$\mathrm{Su}$ hija virgen y asexual. (13-22) 
Perfect rhyme helps the speaker connect the words to create a scornful tone. Rhyming lines like puras/curas and central/asexual denote the unfavorable situation of women in Central America. First of all, the female voice implies that priests have no pure intentions and that in Central America women must be asexual. She continues condemning sexual patriarchal and religious treaties of omnipotence over female sexuality. She not only accuses these institutions of power and oppression but also threatens them with shattering her virginity with the iron of her nipples:

Y de esta fálica

Omnipotencia

Mi rebelión de obreras

Me defienda.

Porque tomo la punta de mis senos,

Campanitas

De agudísimo hierro

Y destierro

Este himen puntual

Que me amordaza

En escozor machista

Y en larga lista

De herencia colonial. (28-40)

She defiantly invokes her rebellion of workwomen to defend her from a phallic omnipotence. She does not clamour for heavenly help, for she will be betraying her gender imploring assistance to a religion that entails the domination of women by men. Her army of workwomen will suffice for this endeavor. She regains power by taking control over her vagina. She mines precepts attributing her nipples warrior-like qualities and enabling them to banish her hymen that muzzles her with machista burning. By personifying her nipples and hymen, Istarú empowers her body. At the end of the poem, she bestows the power to suppress all traits of a colonial identity that has subjugated her indigenous heritage, and she triumphantly annihilates these ideological chains:

Yo borro este tratado de los cráneos,

Con ira de quetzal

Lo aniquilo,

Con militar sigilo

Lo muerdo y pulverizo,

Como a un muerto ajado e indeciso

Lo mato y lo remato

Con mi sexo abierto y rojo,

Manojo cardinal de la alegría,

Desde esta América encarnada y encendida,

Mi América de rabia, la Central. (41-51) 
The ire of the female voice against all forms of oppression is heard through the constant repetition of " $r$ " sound. The use of verbs like "muerdo" (to bite) and "pulvorizo" (to pulverize), "mato" (to murder), and "remato" conveys the rabid anger of the persona and prepares the reader for the climatic end where she is able to murder and re-murder patriarchy, religion, and colonialism with her gaping and red sex. The attributes of "open" and "red" are significant because they suggest that the speaker will no longer hide her sexuality but that she will use it as she pleases. The redness of it may suggest the burning or erotic urge as well as the color of her vagina. She emphasizes this color in the subsequent line where she affirms that her sex is a cardinal bundle of joy. The pun generated by the word "cardinal" subverts her sex. "Cardinal" expresses the paramount significance of female sexuality, her burning sex, and her irreverence toward the Catholic Church, since it also denotes the person ranking next to the Pope.

Istarú employs her erotic poetry to boo the huge overwhelming shadow of hegemonic relationships and provides a space for every woman to champion her sexuality and her essence. In poem XI, she explores her bodily territories with the most ferocious desire:

Mi clítoris destella

en las barbas de la noche

como un pétalo de lava

..............

Al que ataca la dicha,

Al que el placer ataca

Y contraataca

Con zumos delicados (1-7)

Her clitoris bursts into flames in the night's beard like a lava petal. The oxymoronic relation of "lava" and "petal" suggests how her clitoris is a burning and soft entity left at the mercy of the erotic games of the night. She plays with the personification of the night, which, at the same time, constitutes a metonomy for the lover. The oxymoronic imagery continues, when joy and pleasure attack her clitoris with delicate fluids over and over again, until her uterus forgets its soft place of residence and unties the strings of space for the man who traverses her burning satin pubis. Defiantly, in this poem, female genitalia recover their territory and open or close their borders at their heart's wish.

Through her eroticism, Istarú recreates her sexuality and female identity that had been sequestered by phallocentrism. She is her own creation; she is the artifice of her life, which is captured in poem XII:

Yo soy el día.

Mi pecho izquierdo la aurora.

Mi otro pecho es el ocaso

La noche soy. (1-4) 
She proclaims that she is day and night and that her left breast is dawn and her right is twilight. With these metaphors, she affirms that she is her own universe - the Alpha and Omega-her own world where she is the sole ruler, where death is meaningless, and where everything leads to and life starts again:

Mi pubis bebió en la sombra

Negros viñedos, duraznos,

La tempestad.

La rosa recia del viento,

Seda encarnada en mi ovario. (5-9)

She transcends through her sex. Her pubis drinks the fluids of life that taste like dark vineyards and peaches, and the vigorous compass rose is incarnated silk in her ovary, pointing the way towards her ability to give life.

As a conclusion, for both writers, erotic poetry becomes a liberating and empowering force-a space for subversive thought where their uncanny territories become a land of sensual gratification. Their literary works become a window and a mirror to the vast female land. On this land, a new man is allowed to enter-one who does not entail domination over woman-her equal and one with whom she can indulge in heavenly or terrestrial pleasures. I would like to conclude with a quote from Hélene Cixous:

Text: My body....what touches you, the equivoice that affects you, fills your breast with an urge to come to language and launches your force; the rhythm that laughs you; the intimate recipient who makes all metaphors possible and desirable; body (body? Bodies?), no more describable than god, the soul, or the Other; that part of you that leaves a space between yourself and urges you to inscribe in language your woman's style. (882)

\section{Bibliography}

Acón, Lai Sai. "Las variadas estrategias textuales que desestabilizan la cosificación patriarcal de la mujer." Escena. 88-108. Print.

"Angel." Webster's Ninth New Collegiate Dictionary. $2^{\text {nd }}$ ed. 1991. Print.

Arce A., María Eugenia. Inner and Outer World in to The Lighthouse and La Ruta de su Evasión. Diss. University of Costa Rica, 1980. 6655. Print.

"Bernini's Ecstasy of Saint Teresa." Khanacademy. Smarthistory. Web 20 March 2013.

Bowers, Susan R. "Medusa and the Female Gaze." NWSA Journal 2.2 (1990): 217-235. Print.

Cixous, Helene et al. "The Laugh of the Medusa." Signs, 1. 4 (Summer, 1976): 875-893. Print.

Chen, Jorge. "Texto cultural y poesía costarricense: Jorge Debravo y Ana Istarú". Kañina, Revista de Artes y Letras, 30.2 (2006): 103-112. Print. 
Dobles, Julieta. Hojas Furtivas. San José: Editorial Costa Rica, 2007. Print.

Dobles, Julieta. Los Delitos de Pandora. $2^{\text {nd }}$ ed. San José: Editorial Costa Rica, 1999. Print.

Dobles, Julieta. Los Pasos Terrestres. $2^{\text {nd }}$ ed. San José: Editorial Costa Rica, 2003. Print.

Dobles, Julieta. Poemas para Arrepentidos. San José: Editorial Universidad Estatal a Distancia, 2003. Print.

“Erotic." Webster's Ninth New Collegiate Dictionary. $2^{\text {nd }}$ ed. 1991. Print.

Fuchs, Brigitte. "Is 'Erotic'to 'Pornography' as 'Culture' is to 'Primitive'? Racist Aesthetics and Female Sexuality in $19^{\text {th }}$ and $20^{\text {th }}$ century." PDF File.

Istarú, Ana. Baby boom en el paraíso/Hombres en escabeche. San José: Editorial Costa Rica, 2001. Print.

Learned, Amer. El erotismo como logro del movimiento feminista en Centroamérica: Los casos de Ana Istarú, Dina Posada y Jacinta Escudos. Diss. University of Saskatchewan, Saskatoon, 2008. PDF File.

Lorde, Audre. Uses of the Erotic : Erotic as Power. Tucson: Kore Press, 2000. Print.

Montero B., María Gabriela. Las figuras bartheanas y el discurso amoroso en Estación de Fiebre. Diss. University of Costa Rica, 1998. 18754. Print.

Mora E., Sonia \& Flora Ovares R. Indómitas Voces: Las poetas de Costa Rica, Antología. San José: Editorial Mujeres, 1994. Print.

Mosby, Dorothy E. "The Erotic as Power: Sexual Agency and the Erotic in the Work of Luz Argentina Chiriboga and Mayra Santos Febres." Cincinnati Romance Review 30 (Winter 2011): 83-98. Print.

Paz, Octavio. La llama doble: Amor y erotismo. México D. F.: Editorial Planeta Mexicana, 1994. PDF File.

Robb, Anthony J. Eunice Odio y su sensual mundo poético. Ontario: The Edwin Mellen Press, 2010. Print.

Solórzano Alfaro, Gustavo. Retratos de una Generación Imposible: Muestra de 10 poetas costarricenses y 21 años de su poesía (1990-2010). San José: Editorial Universidad Estatal a Distancia, 2010. Print. 
